STUDIA HISTORYCZNE

R. LXI, 2018, z. 2 (242), s. 107-110

https://doi.org/10.12797/SH.61.2018.02.08

\title{
Krzysztof Kubiak, Łukasz Mamert Nadolski, Ogień na pustyni. Konflikt izraelsko-arabski w latach 1967-1973
}

Zabrze-Tarnowskie Góry: Wydawnictwo Inforteditions 2017, ss. 200, ISBN 978-83-6402-391-0

Od II wojny światowej Bliski Wschód pozostaje jednym z głównych punktów zapalnych świata. Państwo żydowskie powstało w roku 1948 na drodze zbrojnej konfrontacji ze wszystkimi sąsiadami, z którymi ścierało się następnie regularnie w kolejnych dekadach swojego istnienia. Konflikty te mają już w Polsce swoją literaturę naukową. O ile jednak wojna sześciodniowa, kryzys sueski czy wojna Jom Kippur były już wielokrotnie opisywa$\mathrm{ne}^{1}$, o wiele gorzej ma się sytuacja z okresami pomiędzy tymi wydarzeniami.

Lukę tę starają się wypełnić swoją nową książką prof. dr hab. Krzysztof Kubiak i dr Łukasz Mamert Nadolski². Poświęcona jest ona okresowi między wojną sześciodniową i wojną Jom Kippur, nazywanym w literaturze przedmiotu wojną na wyczerpanie. Mimo spektakularnego sukcesu militarnego Izraela w pierwszych dniach czerwca 1967 r. zawieszenie broni nie oznaczało bowiem bynajmniej spokoju - już 17 czerwca przedstawiciele 13 arabskich państw ogłosili powstanie wspólnego frontu przeciw państwu żydowskiemu. Choć o oficjalnym konflikcie można mówić dopiero od marca 1969 r., gdy Gamal Abdel Naser publicznie wypowiedział zawieszenie broni z czerwca 1967 r., to w praktyce do starć wzdłuż nowych granic Izraela zaczęło dochodzić natychmiast po zawieszeniu broni.

Książka podzielona jest na sześć rozdziałów. Zaznaczyć trzeba jednak, że objętościowo prawie połowę stanowi rozdział I Wojna na wyczerpanie - dziatania na lądzie i w powietrzu, poświęcony starciom pomiędzy Egipcjanami i Izraelczykami, ze szczególnym naciskiem na zmagania w powietrzu. Dominują w nim więc opisy walk powietrznych między maszynami Hel Ha’Avir i lotnictwa egipskiego oraz zwalczania przez Izraelczyków stale rozbudowywanej rakietowej obrony przeciwlotniczej przeciwnika. Przybliżone zostały

1 Z nowszych publikacji warto wskazać: R. Marcinek, Kanat Sueski 1956, Warszawa 2017, ss. 267; K. Kubiak, Ł.M. Nad olski, Wojna sześciodniowa 1967, Zabrze-Tarnawskie Góry 2016, ss. 392.

2 Obaj autorzy pisali już wcześniej samodzielnie o wojnach państwa żydowskiego, nie jest to także ich pierwsza kooperacja. Oprócz wymienionej powyżej Wojny sześciodniowej 1967 współtworzyli także książki poświęcone wojnie hindusko-chińskiej z roku 1962 oraz działaniom lądowym w trakcie konfliktu o Falklandy: Klęska na dachu świata. Armia indyjska w wojnie granicznej z Chinami w 1962 roku, Toruń 2015, ss. 250; Dziatania wojsk ladowych w czasie wojny falklandzkiej, Warszawa 2013, ss. 287. 
także rajdy komandosów obu stron oraz stopniowy wzrost zaangażowania po stronie Egiptu Związku Radzieckiego, który doprowadził do bezpośrednich walk powietrznych oraz dramatycznych ataków lotniczych Izraelczyków na superbaterię rakiet przeciwlotniczych SA-2 i SA-3, stworzoną przez Rosjan i Egipcjan.

Rozdział II Atak na Zielona Wyspę poświęcony jest w całości zuchwałemu rajdowi izraelskich komandosów na silnie ufortyfikowaną egipską twierdzę w Zatoce Sueskiej, przeprowadzonemu 20 lipca 1969 r. Choć oficjalnie chodziło o zniszczenie znajdującej się $\mathrm{w}$ fortecy artylerii przeciwlotniczej, atak miał w rzeczywistości na celu zademonstrowanie Egipcjanom, że ich przeciwnicy są w stanie skutecznie uderzyć w dowolny punkt w ich kraju, nieważne, jak silnie umocniony i przygotowany do obrony. Rajd miał więc przede wszystkim istotne znaczenie symboliczne i polityczne, przeprowadzono go zresztą na wyraźne żądanie najwyższych ośrodków decyzyjnych w Izraelu.

W rozdziale III Wojna na wyczerpanie na morzu opisano kilka incydentów, do jakich doszło na wodach rozdzielających wojujące strony. Do najważniejszych należało zatopienie niszczyciela INS Elath ${ }^{3}$, zawiłe okoliczności przejścia (czy też w zasadzie ucieczki) izraelskich ścigaczy rakietowych typu Sảar z Francji do Izraela w roku 1968 oraz zniszczenie przez egipskie rakiety kutra rybackiego Orit.

Rozdział IV Drugi front wojny na wyczerpanie - Jordania, Syria i Liban odrywa czytelnika od głównego frontu walki wzdłuż Kanału Sueskiego i przenosi go na północne oraz wschodnie granice Izraela. Z większymi szczegółami opisana została w nim między innymi bitwa pod Karamah, gdy podczas ataku na obóz palestyńskich bojowników doszło do starcia pomiędzy izraelskimi i jordańskimi oddziałami pancernymi. Autorzy opisali także rajd helikopterowy przeprowadzony przez Izraelczyków na lotnisko w Bejrucie w grudniu 1968 r., który podobnie jak atak na Zieloną Wyspę miał charakter zarówno wojskowy, jak i polityczny. Przedstawione zostały także liczne incydenty, do jakich dochodziło w północno-wschodnim pasie przygranicznym, tak na lądzie, jak i w powietrzu, zwłaszcza nad odebranymi Syrii Wzgórzami Golan.

Rozdział V Czarny Wrzesień skupia się na krytycznym dla jordańskiej państwowości okresie, gdy władzy dynastii Haszymidów otwarte wyzwanie rzuciły organizacje palestyńskich bojowników, wykorzystujące fakt, że po ucieczce z nowo powstałego Izraela masy uchodźców około 70\% mieszkańców Jordanii stanowili Palestyńczycy. Autorzy opisali zarówno motywację poszczególnych stron, jak i przebieg walk, które mimo największego ich nasilenia we wrześniu 1970 r. toczyły się zarówno na kilka miesięcy przed, jak i kilka po tym miesiącu.

Rozdział VI Straty jest w zasadzie aneksem, skrótowo informującym czytelnika o stratach w ludziach i sprzęcie wojujących stron.

3 Warto tu zwrócić uwagę, że autor stosuje hebrajską nazwę jednostki nawiązującą do starożytnej nazwy miasta Ejlat, w publikacjach anglojęzycznych niszczyciel funkcjonuje jako Eilat. 
Książka opatrzona została przypisami i bibliografią, ale brakuje indeksów. Co jest dość zastanawiające, bardzo ubogo przedstawia się materiał ilustracyjny, sprowadzający się w zasadzie do kilku dość prostych schematów ukazujących ataki izraelskiego lotnictwa na sowiecko-egipską superbaterię w czerwcu i lipcu 1970 r. W publikacji znajduje się także tylko jedna, bardzo ogólna mapa regionu, co przy znacznej egzotyce geograficznej tematu mocno zmniejsza czytelność opisywanych wydarzeń.

$\mathrm{Na}$ plus z kolei zaliczyć należy liczne tabele umieszczone zarówno w samych rozdziałach, jak i w formie załączników, które pozwalają uporządkować i podsumować informacje podane w samym tekście. W części rozdziałów znajdują się także ramki z dodatkowymi informacjami.

Książkę napisało dwóch autorów i sprawia ona przez to wrażenie dość nierównej w trakcie lektury. Zaznaczyć trzeba przy tym, że nie o chodzi o poziom naukowy, który pozostaje wysoki, ale raczej kwestie związane z wyraźnie odmiennym stylem Kubiaka i Nadolskiego. Poszczególne rozdziały stanowią tak naprawdę osobne, zamknięte artykuły poświęcone interesującym, zróżnicowanym kwestiom, pisane jednak chyba w znacznym stopniu niezależnie od siebie i zebrane w jednej książce ze względu na dość ogólną wspólnotę tematyki, jaką jest okres wojny na wyczerpanie. Mimo różnic w stylu Ogień na pustyni czyta się dobrze, zaś w tekście odnaleźć można tylko pojedyncze literówki.

Książka pisana jest z perspektywy izraelskiej, co widać zarówno w narracji, jak i zawartości bibliografii. Wynika to zapewne z kilku czynników. Po angielsku zdecydowanie więcej pisali i nadal piszą sami Izraelczycy. $\mathrm{Na}$ dodatek materiały publikowane przez stronę arabską (oraz sowiecką) miały bardzo często charakter czysto propagandowy, zaś dostęp do archiwów jest utrudniony, jeżeli nie wręcz niemożliwy. Warto tu jednak pamiętać, że także strona izraelska bardzo ostrożnie udostępnia swoje dokumenty, co sprawia, że szereg kwestii mimo upływu lat pozostaje wciąż w sferze domysłów lub opiera się wyłącznie na wspomnieniach osób zaangażowanych, jak chociażby opisywane w książce okoliczności zatopienia niszczyciela INS Elath ${ }^{4}$. Sami autorzy zdają sobie sprawę z dysproporcji i subiektywności materiałów, z których korzystają ${ }^{5}$, skrzywienie w stronę izraelską jest jednak widoczne.

Czytając Ogień na pustyni, można odnieść wrażenie, że jest to bezpośrednia kontynuacja wydanej rok wcześniej Wojny sześciodniowej tych samych autorów. Widać to chociażby po braku krótkich biogramów najważniejszych decydentów wojujących stron. Autorzy zakładają także obeznanie czytelnika ze sprzętem wojskowym wykorzystywanym przez walczących, zarówno z samolotami, jak i pojazdami sił lądowych. Ujawnia się przy tym wspomniana nierówność poszczególnych rozdziałów, gdyż w rozdziale trzecim, poświęconym

\footnotetext{
4 K. Kubiak, Ł.M. Nadolski, Ogień na pustyni. Konflikt izraelsko-arabski w latach 1967-1973, ZabrzeTarnowskie Góry 2017, s. 119-120.

5 Ibidem, s. 6.
} 
działaniom na morzach, pokrótce opisane są tak jednostki izraelskie ${ }^{6}$ oraz egipskie, jak i nawet przeciwokrętowy pocisk rakietowy Gabriel. W przypisach do tego rozdziału znajdziemy także krótkie biogramy osób zaangażowanych w nielegalną ewakuację izraelskich ścigaczy rakietowych z Francji, takich jak admirał Mordechaj Limon czy Félix Amiot. Zastanawiający jest $\mathrm{z}$ kolei $\mathrm{w}$ tym rozdziale brak jakiejkolwiek wzmianki o tajemniczym losie INS Dakar. Zaginięcie tego izraelskiego okrętu podwodnego w styczniu 1968 r., którego zatopienie starali się w późniejszych latach przypisać sobie Egipcjanie, niewątpliwie wpisuje się w tematykę wojny na wyczerpanie ${ }^{8}$.

Mimo że obaj autorzy podkreślają w wielu miejscach polityczno-propagandowe znaczenie poszczególnych starć powietrznych i akcji oddziałów specjalnych, w książce brakuje umocowania tego pełzającego konfliktu w szerszym kontekście wielkiej światowej polityki. Chociaż po raz kolejny zależy to od rozdziału. Najbardziej odczuwalne jest to w pierwszym rozdziale, skupiającym się na militarnym aspekcie egipsko-izraelskich zmagań wzdłuż Kanału Sueskiego, zwłaszcza walk powietrznych. Wielka polityka pojawia się o wiele wyraźniej w rozdziałach trzecim i piątym.

Podsumowując: Ogień na pustyni. Konfikt izraelsko-arabski w latach 1967-1973 jest książką interesującą i sprawnie napisaną, przybliżającą czytelnikowi tematykę dotychczas tylko ogólnie zarysowywaną w podsumowaniach książek poświęconych wojnie sześciodniowej lub we wstępach do publikacji opisujących wojnę Jom Kippur. Objętościowo dominuje w niej pierwszy rozdział, skrupulatnie, dzień po dniu i starcie po starciu przedstawiający izraelsko-egipskie walki w rejonie Kanału Sueskiego. O ile główny nacisk położono w nim na starcia powietrzne i zwalczanie egipskiej obrony przeciwlotniczej, o tyle zawiera także szereg interesujących informacji o działaniach sił specjalnych obu stron oraz, co chyba najcenniejsze, o bezpośrednim udziale w tych walkach pilotów i przeciwlotników ZSRR z 135 Pułku Myśliwskiego oraz 18 Samodzielnej Dywizji Rakiet Przeciwlotniczych. Pozostałe rozdziały są o wiele mniejsze od pierwszego, choć przyznać trzeba, iż wynika to także z faktu, że największą intensywność starcia osiągały na odcinku egipskim. Mimo to można zauważyć w tej książce, iż pisało ją dwóch autorów, a zmiany stylu są odczuwalne i wpływają na dość nierówne wrażenie, jakie mamy po zakończeniu lektury. Pomimo tych uwag stanowi ona cenne uzupełnienie dotychczasowej literatury, zwłaszcza w połączeniu z wcześniejszą publikacją obu autorów poświęconą wojnie sześciodniowej.

Jarema Stowiak

6 Niszczyciel INS Elath, ścigacze typu Sa’ar i Reshef.

7 Otrzymane od ZSRR ścigacze rakietowe typu Komar (projekt 183R).

8 Okręt odnaleziono dopiero w roku 1999 na dnie morskim pomiędzy Kretą i Cyprem, na głębokości 3 km. 